\title{
ANATOMY AND ONTOGENY OF Pterodon emarginatus (FABACEAE: FABOIDEAE) SEED
}

\author{
OLIVEIRA, D. M. T. ${ }^{1}$ and PAIVA, E. A. S. ${ }^{2}$ \\ ${ }^{1}$ Dep. Botânica, Instituto de Biociências, UNESP - Universidade Estadual Paulista, C.P. 510, \\ CEP 18618-000, Botucatu, SP, Brazil \\ ${ }^{2}$ Dep. Botânica, Instituto de Ciências Biológicas, Universidade Federal de Minas Gerais, \\ CEP 31270-901, Belo Horizonte, MG, Brazil \\ Correspondence to: Denise Maria Trombert Oliveira, Dep. Botânica, Instituto de Biociências, UNESP - \\ Universidade Estadual Paulista, C.P. 510, CEP 18618-000, Botucatu, SP, Brazil, e-mail: denise@ibb.unesp.br \\ Received July 10, 2003 - Accepted October 27, 2003 - Distributed August 31, 2005
}

(With 30 figures)

\begin{abstract}
The aim of this study was to describe the anatomy and ontogeny of Pterodon emarginatus seed using the usual techniques. The ovules are campilotropous, crassinucelate, and bitegmic. The following processes occur during integument development: anticlinal divisions and phenolic compound accumulations in the exotesta, whose cells become palisade; predominantly periclinal divisions and cell expansion in the mesotesta, where the rapheal bundle differentiates; differentiation of the hourglasscell layer adjacent to the palisade; fusion of outer and inner integuments, which remain individualized structures only at the micropylar end; and intense pectin impregnation in the mesotesta thicker walls with lignification restricted to the xylem. At the hilar pole, the Faboideae seed characteristic structure develops, with double palisade layer, subhilar parenchyma, and tracheid bar. The younger nucellus shows thicker pectic cell walls and is consumed during seed formation. The endosperm is nuclear and, after cellularization, shows peripheral cells with dense lipid content; the seeds are albuminous. The axial embryo shows fleshy cotyledons, which accumulate lipid and protein reserves; starch is rare. Although the seed structure is characteristic of the Fabaceae, the inner integument coalesces into the outer integument without being reabsorbed.
\end{abstract}

Key words: cerrado vegetation, Fabaceae, Pterodon emarginatus, seed anatomy, seed-coat.

\section{RESUMO}

\section{Anatomia e ontogênese da semente de Pterodon emarginatus (Fabaceae: Faboideae)}

O presente trabalho foi desenvolvido com o objetivo de descrever a estrutura da semente de Pterodon emarginatus, nas várias fases do desenvolvimento, utilizando técnicas usuais. Verificou-se que os óvulos são campilótropos, crassinucelados e bitegumentados. Durante o desenvolvimento tegumentar ocorrem os seguintes processos: divisões anticlinais e acúmulo de compostos fenólicos na exotesta, cujas células tornam-se paliçádicas; divisões predominantemente periclinais e alongamento na mesotesta, onde se diferencia o feixe rafeal; diferenciação, adjacente à paliçada, da camada de células em ampulheta; coalescimento do tégmen junto à testa, culminando no concrescimento dos dois tegumentos, que se mantêm individualizados apenas na região micropilar; intensa impregnação de compostos pécticos nas paredes espessadas da mesotesta, com lignificação restrita ao xilema. Na região hilar, desenvolve-se a estrutura característica das sementes de Faboideae, com dupla camada paliçádica, parênquima subhilar e barra de traqueídes. O nucelo é consumido durante a formação da semente, observando-se, na estrutura jovem, células de paredes pécticas espessadas. O endosperma é nuclear e, após a celularização, exibe perifericamente células de conteúdo denso; é encontrado na semente madura, embora se apresente reduzido, acumulando substâncias lipídicas. O embrião é axial, com cotilédones crassos, que acumulam 
reservas de natureza lipídica e protéica, sendo raros os grãos de amido. Embora a estrutura observada seja típica das Fabaceae, não há reabsorção do tegumento interno, mas concrescimento ao externo.

Palavras-chave: cerrado, Fabaceae, Pterodon emarginatus, anatomia de semente, tegumento seminal.

\section{INTRODUCTION}

The Fabaceae family (= Leguminosae) consists of approximately 650 genera and 18,000 species; it is one of the largest Angiosperm families (Polhill et al., 1981; Judd et al., 1999). The Faboideae is the largest of the three Fabaceae subfamilies with about 440 genera and 12,000 species (Polhill, 1981a). Many species occur in tropical regions, and are a significant part of the Aeschynomeneae, Dalbergieae, Dipteryxeae, and Sophoreae tribes centered in Latin America (Raven \& Polhill, 1981). The three Dipteryxeae genera occur only in Central and South America, mainly in the Amazon region (Polhill, 1981b).

Of the Faboideae, the Dipteryxeae tribe is characterized by presenting a single subapical ovule in the ovary. Its seeds are oblong-fusiform to compressed-ovoid, with a short straight radicle, sometimes embedded in the cotyledons (Polhill, 1981b).

It is important to emphasize that seed morphology usually shows little phenotipic plasticity. On the other hand, embryological characters, usually constant in the genera, function as a significant indicator of taxonomic affinity (Von Teichman \& Van Wyk, 1991). According to these authors, there are few descriptive and ontogenetic studies on seed structure, which makes speculating about evolutive trends affecting seeds very difficult.

Pterodon emarginatus, commonly known as sucupira, frequently occurs in the Brazilian cerrado and in transition areas approaching the Paraná river basin semideciduous forest. Despite its slow growth, this species is important, due to its tolerance of direct sunlight and low soil fertility in mixed reforestations designed to recover degraded areas (Lorenzi, 1992). The aim of this study was to describe the anatomy and ontogeny of Pterodon emarginatus seed, emphasizing its testa and reserve-tissue occurrence and structure.

\section{MATERIAL AND METHODS}

Ovaries of anthesis flowers, young fruit in different developmental stages, and mature Pterodon emarginatus J. Vogel (synonym: Pterodon pubescens Benth.) fruit were collected from the Botucatu cerrado, São Paulo, Brazil. Fertile branches were collected and deposited at the Irina D. Gemtchujnicov Herbarium (BOTU) of the Department of Botany, UNESP, Botucatu, as vouchers.

Anatomical studies were performed in fresh and fixed materials. For historesin infiltration, samples were fixed in FAA50 (Johansen, 1940) or Karnovsky's mixture (Karnovsky, 1965). After 24 $\mathrm{h}$ fixation, the samples were transferred to $70 \%$ ethyl alcohol (Jensen, 1962) and stored for processing. Mature seeds were soaked in distilled water for 12 $\mathrm{h}$ before fixation. They were dehydrated by ethanol series (Johansen, 1940) and submitted to historesin infiltration (Leica Embedding Kit), as per standard methods. A rotary microtome supplied longitudinal and transverse sections $(5 \mu \mathrm{m})$ of the samples. After staining with toluidine blue (O'Brien et al., 1964), the slides were mounted with Entellan. Freehand sections were only used when necessary for histochemical tests and preliminary studies.

We performed the following tests: acidified phloroglucin for lignin detection (Sass, 1951); Sudan IV for lipids; $10 \%$ aqueous ferric chloride for phenolic compounds; Lugol for starch; ruthenium red for pectic compounds (Johansen, 1940), and bromophenol blue for proteins (Mazia et al., 1953).

\section{RESULTS}

Pterodon emarginatus ovules are campilotropous, crassinucelate, and bitegmic (Fig. 1). The outer integument shows three to five layers of isodiametric cells; the inner integument has two to three layers of slightly flattened cells in a periclinal plane (Fig. 2). The micropyle is zigzag, with a larger number of cell layers in the exostome. The nucellus is composed of some layers of dense cells and a large nucleus, with evident megaspore mother cell in the central region (Figs. 1-2).

Many alterations occur in the beginning of seed ontogeny, when the young fruits are about $0.4 \mathrm{~cm}$ in length. The mesophyll cells of the outer integument 
(mesotesta) are isodiametric or slightly flattened, with evident nucleus and numerous divisions in different planes. The outer epidermis (exotesta) of the epidermis is denser than the other layers, with cubic cells showing slight radial elongation (Figs. 3-4). This layer presents only anticlinal divisions. In this phase, the nucellus is almost entirely consumed. We observe very few residual cell layers around the developing nuclear endosperm (Fig. 3); nucellar residues remain in large amounts at the chalazal pole. Notice that the nucellus cells start to become longitudinally elongated and rounded in transverse section; their thick cell walls present intense pectic impregnation (Figs. 34).

In seeds of about $1.2 \mathrm{~cm}$-long fruits, we observe phenolic compound accumulation in small vacuoles of the exotesta cells (Figs. 5-6). The mesotesta continues to present cell divisions in different, mainly periclinal planes (Figs. 5-6). The endotesta does not differentiate; the inner integument coalesces into the outer one, although they are still distinct in this stage (Figs. 57). At the micropylar pole, the individuality of both integuments remain, distinguishing the endostome from the exostome (Fig. 8).
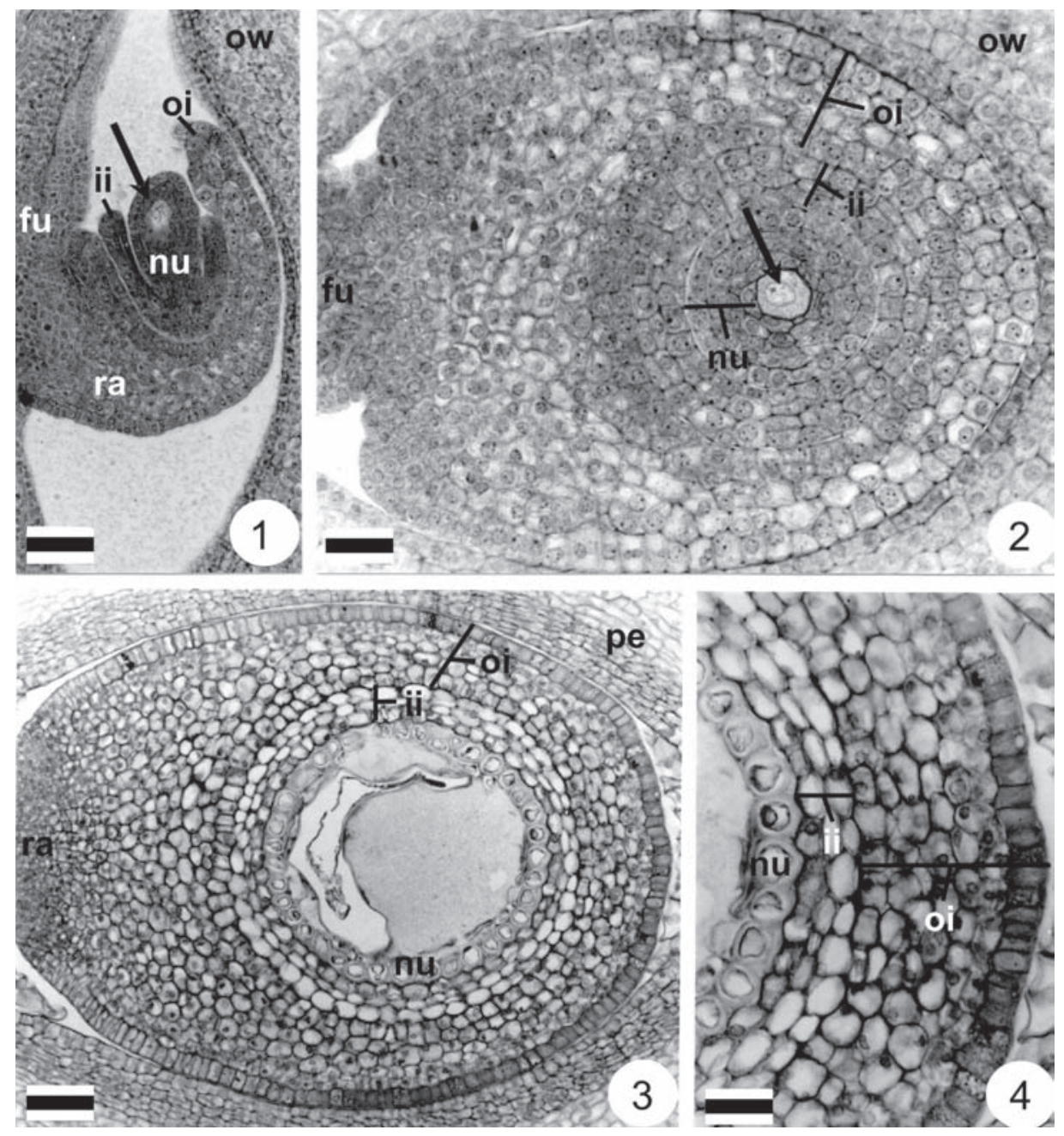

Figs. 1-4 - Initial phases of seed development in Pterodon emarginatus. 1-2. Anthesis flower ovule in longitudinal and transverse section, respectively; arrow indicates the megaspore mother cell (1) and the functional megaspore (2). 3-4. Transverse sections of young seed from fruits $0.4 \mathrm{~cm}$ in length. 3. General view. 4. Detail of the integument and nucellus. (fu: funicle, ii: inner integument, nu: nucellus, oi: outer integument, ow: ovary wall, pe: pericarp, ra: raphe). Bars: $50 \mu \mathrm{m}(1,3), 25 \mu \mathrm{m}(2,4)$. 
When the fruits are between 2 and $3 \mathrm{~cm}$ in length, the seed-coat remains as described above (Fig. 9), but a significant increase is seen in the endosperm, which is still coenocytic (Figs. 10-11). In this phase, the globular embryo and the suspensor are evident (Figs. 10-11). The nucellus is now restricted to the chalazal pole, but still evident (Fig. 12).

Seed development continues, with increase in size, resulting mainly from anticlinal divisions in the integument and intense endosperm increase. From the micropylar pole, the endosperm initiates centripetal cellularization around the embryo (Fig. 13). Seeds reach their final dimensions in full size but imature fruits (about $4.5 \mathrm{~cm}$ ). In this phase, the exotesta of the seed-coat presents radially elongated cells with pectic walls, which form the palisade layer (Figs. 1315). The mesotesta presents loose arrangement; the inner integument is not individualized, but coalesced into the outer one (Figs. 14-16). The amphicribal rapheal bundle is seen in the mesotesta, with increased size at the chalazal pole (Figs. 14-15).
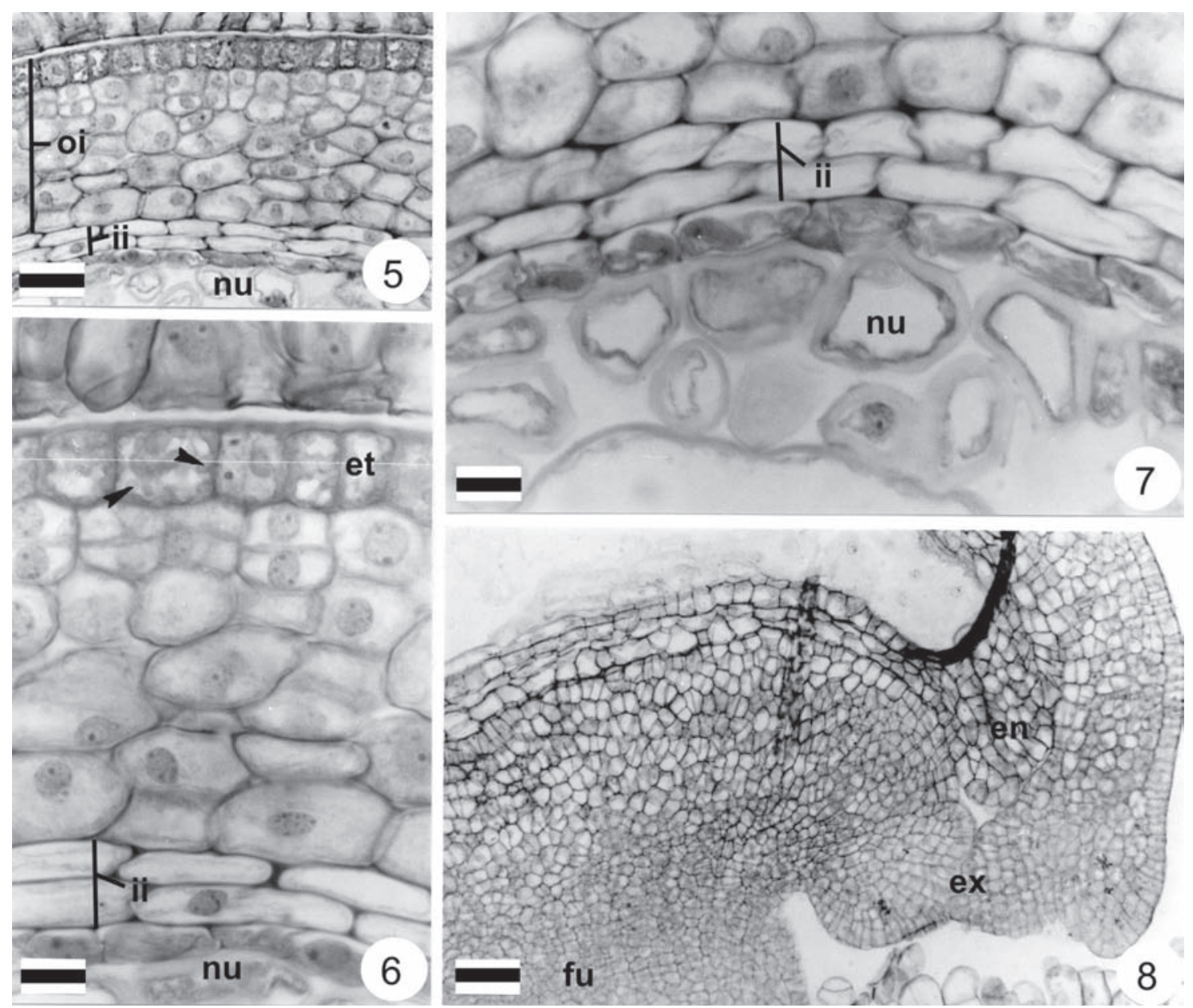

Figs. 5-8 - Pterodon emarginatus young seed from fruits $1.2 \mathrm{~cm}$ in length (transverse sections, except for 8 , which is longitudinal). 5. Integument and nucellus general view. 6. Detail of juxtaposed outer and inner integuments (arrowhead indicates vacuole with phenolic compounds). 7. Detail of the inner integument and nucellus. 8. Micropyle in zigzag. (en: endostoma, et: exotesta, ex: exostoma, fu: funicle, ii: inner integument, nu: nucellus, oi: outer integument). Bars: $50 \mu \mathrm{m}(8), 25 \mu \mathrm{m}(5), 10 \mu \mathrm{m}(6-7)$. 
In the micropyle, the endostome and exostome are individualized (Figs. 18-20). The inner integument is only distinct in this region (Figs. 19-20). In this phase, hilum-region differentiation occurs, with the beginning of tracheid-bar development and double palisade formation (Figs. $18,21)$. The endosperm finishes its cellularization, showing great cytoplasmic density in two or three external peripheral layers (Figs. 17-18). The embryo is axial with two cotyledons joined to the short, straight embryo axis; the suspensor is evident (Figs. $13,18-20)$. The young embryo shows cells with welldeveloped vacuomes in the cotyledons, which do not have reserve accumulation (Figs. 22, 25).
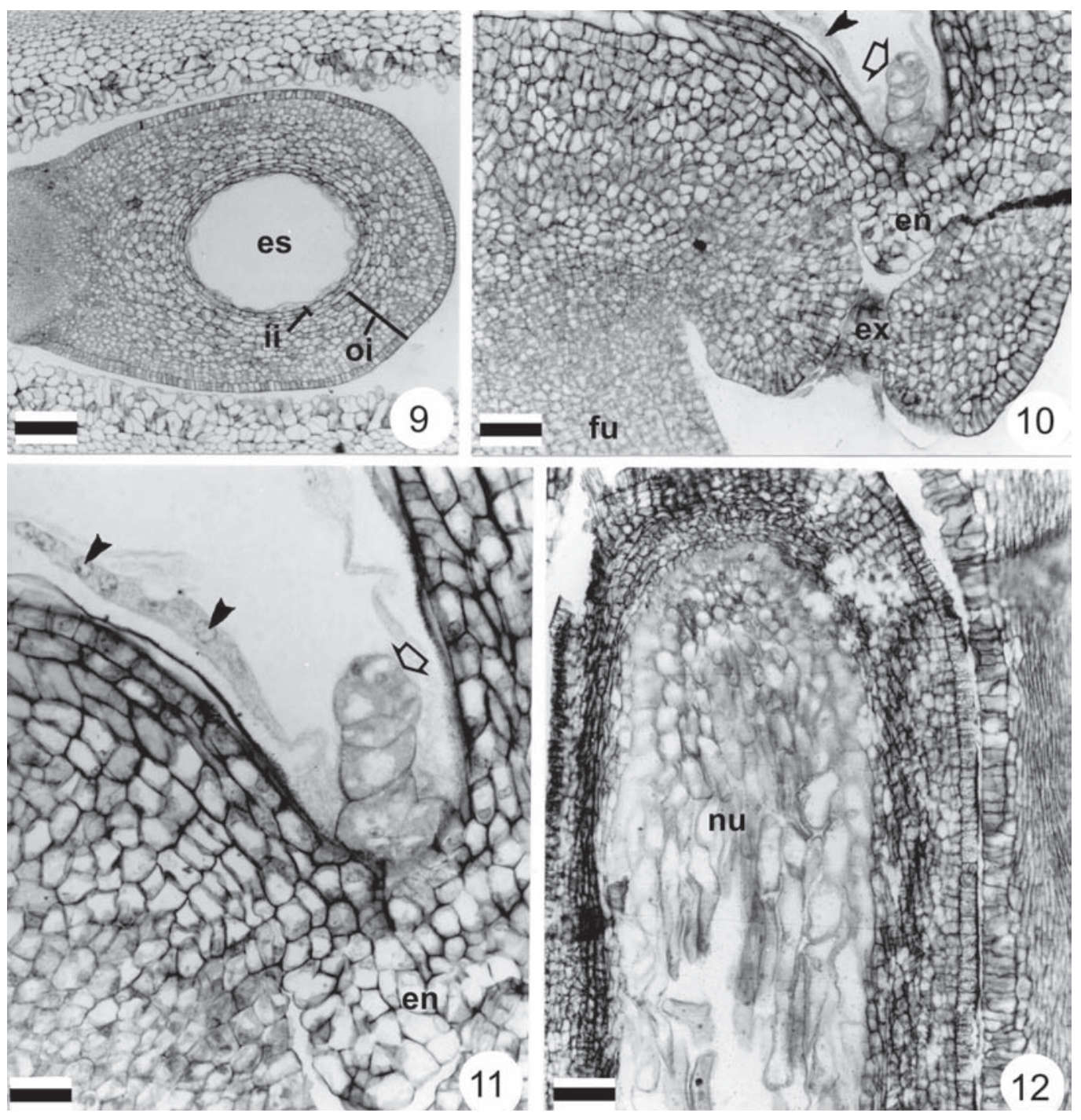

Figs. 9-12 - Pterodon emarginatus young seed from fruits 2 to $3 \mathrm{~cm}$ in length (longitudinal sections, except for 9, which is transverse). 9. General view of the seed. 10-11. Micropylar pole showing globular embryo (arrow) and nuclear endosperm (arrowhead indicates free nuclei). 12. Chalazal region with evident nucellar tissue. (en: endostoma, es: endosperm, ex: exostoma, fu: funicle, ii: inner integument, nu: nucellus, oi: outer integument). Bars: $100 \mu \mathrm{m}(9), 50 \mu \mathrm{m}(10,12), 25 \mu \mathrm{m}(11)$. 

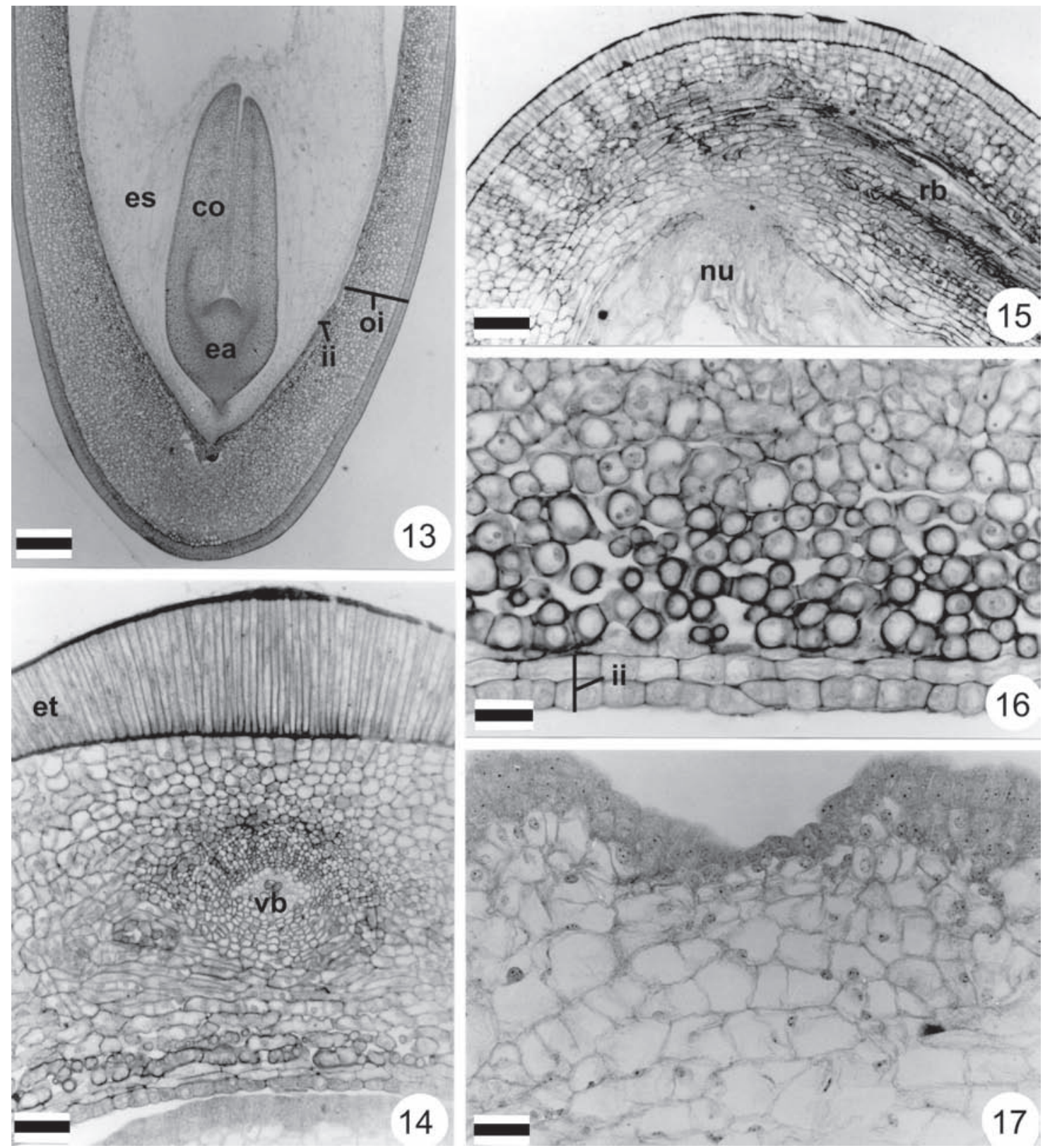

Figs. 13-17 - Pterodon emarginatus young seed from fruits about $4.5 \mathrm{~cm}$ in length (transverse sections, except 13 and 15 , which are longitudinal). 13. General view. 14-15. Chalaza. 16. Detail of the mesotesta inner region and the coalescence of the outer and inner integuments. 17. Detail of the endosperm. (co: cotyledon, ea: embryo axis, es: endosperm, et: exotesta, ii: inner integument, nu: nucellus, oi: outer integument, rb: rapheal bundle, vb: vascular bundle). Bars: $200 \mu \mathrm{m}(13), 50 \mu \mathrm{m}(14,17), 25 \mu \mathrm{m}(15-16)$. 
In mature seeds, the subepidermal layer of the testa differentiates into hourglass-cells; the mesotesta presents many intercellular spaces (Fig. 22). Internally, the seed-coat presents two or three layers of small juxtaposed cells, which originate from the inner integument (Figs. 22-23). The chalaza is characterized by rapheal bundle enlargement (Fig. 23). At this pole, small residues of nucellus cells are still found (Fig. 23). The hilum region finishes differentiation (Figs. 2425). A parenchymatic palisade layer with a single vascular bundle is visible, one of the two layers of which is contiguous to the funicle. The tracheid bar is differentiated and surrounded by loose parenchyma with phenolic cells in the subhilar region (Figs. 24-25).
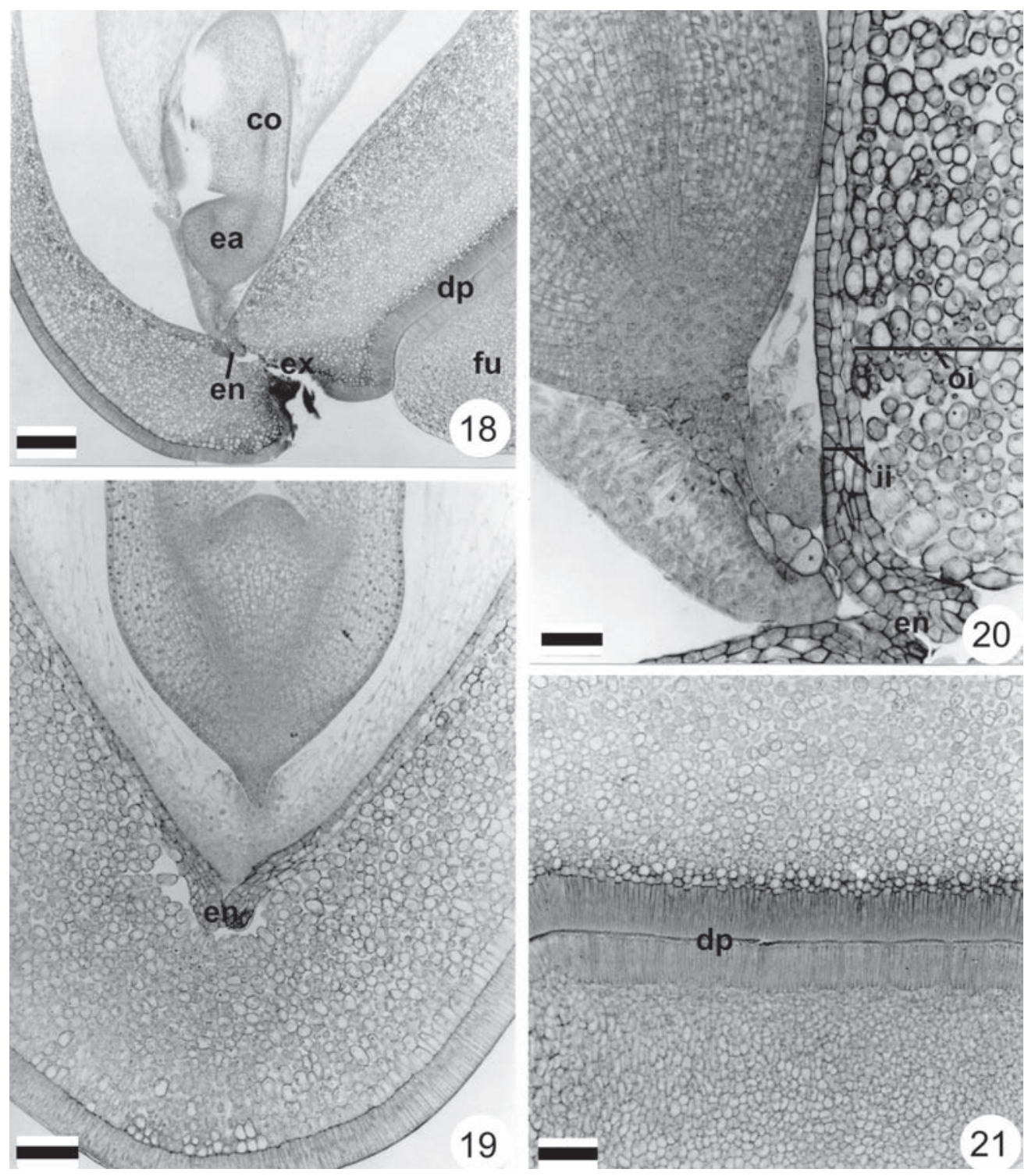

Figs. 18-21 - Pterodon emarginatus young seed from fruits about $4.5 \mathrm{~cm}$ in length (longitudinal sections). 18. General view of the hilum-micropylar region. 19-20. Details of the micropyle region; in 20, notice coalescence of the inner and outer integuments and the suspensor connected to the embryo axis radicular portion. 21. Detail of hilum, with the beginning of palisade layer duplication. (co: cotyledon, dp: double palisade layer, ea: embryo axis, es: endosperm, en: endostoma, ex: exostoma, fu: funicle, ii: inner integument, oi: outer integument). Bars: $200 \mu \mathrm{m}(18), 100 \mu \mathrm{m}(19,21), 50 \mu \mathrm{m}(20)$. 
In mature and soaked seeds, the testa shows thickwalled cells in all layers, with conspicuous intercellular spaces between hourglass cells; intense compression of the mesotestal layers occurs (Figs. 26-28). In the exotesta, wall thickening is cellulosic, and pectic in the mesotesta; the hourglass-cell walls are pectocellulosic. Pectic compounds predominate in the other cell layers. In the testa, lignification is restricted to the rapheal- bundle tracheal elements. Large amounts of phenolic compounds remain in the subhilar-region parenchyma (Fig. 29). The endosperm remains in the mature seed. The last-phase characteristics of the endosperm are preserved even after imbibition, when large amounts of lipids accumulated during maturation are observed. This also occurs, and was also seen after imbibition, with respect to the cotyledons, which become fleshy (Figs. 26, 30) through the accumulation of both lipids and protein; starch grains are rare.
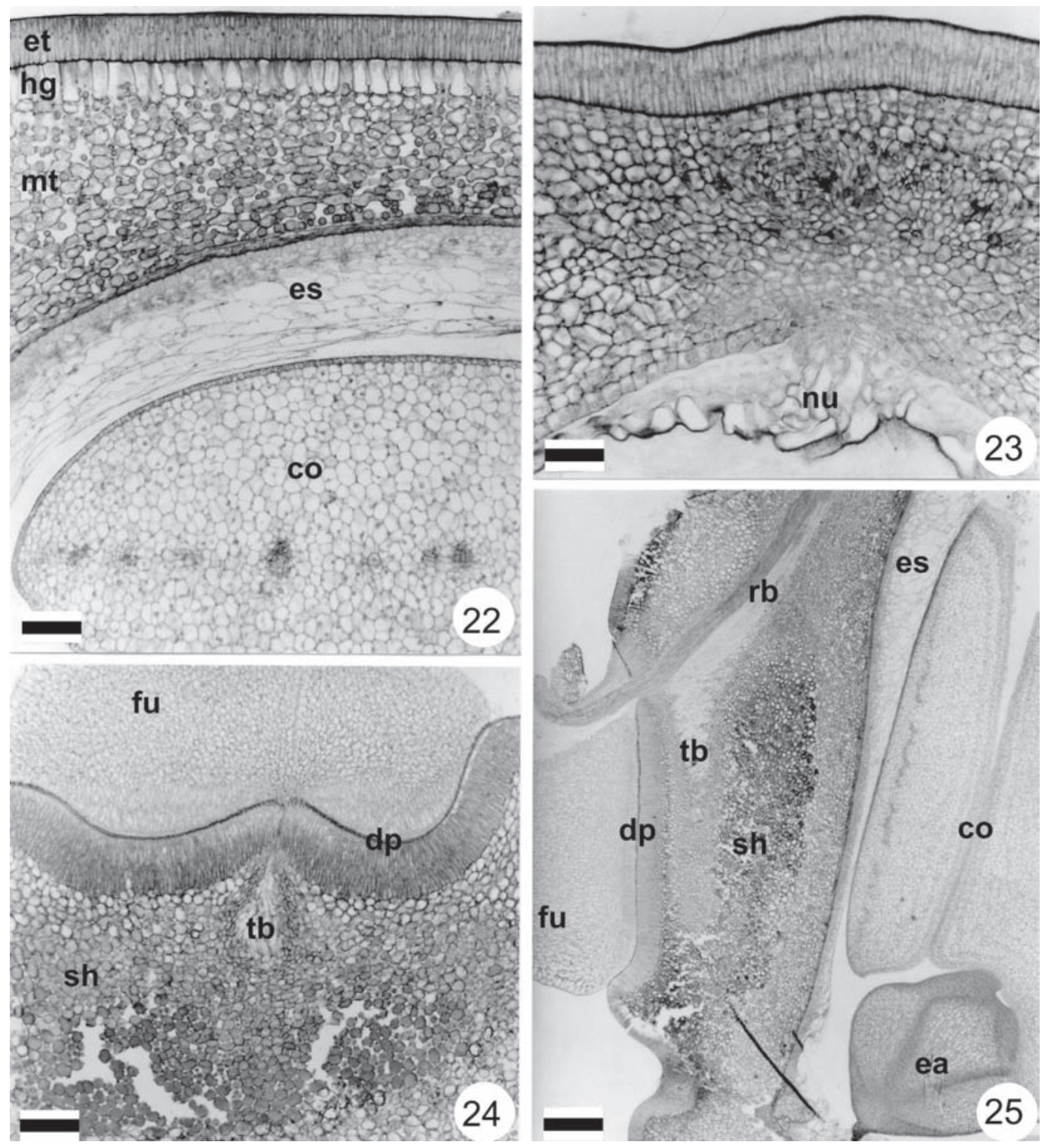

Figs. 22-25 - Pterodon emarginatus mature seed (transverse sections except for 25, which is longitudinal). 22 . General view of the seed, showing the testa, endosperm, and cotyledon. 23. Chalaza. 24-25. Hilum region. (co: cotyledon, dp: double palisade layer, ea: embryo axis, es: endosperm, et: exotesta, fu: funicle, hg: hourglass-cells, mt: mesotesta, nu: nucellus, rb: rapheal bundle, sh: subhilar parenchyma, tb: tracheid bar). Bars: $200 \mu \mathrm{m}(25), 100 \mu \mathrm{m}(22,24), 50 \mu \mathrm{m}(23)$. 
The embryo axis shows a clear distinction between the hypocotyle-radicle and epicotyle regions, the plumule being poorly differentiated (Fig. 30).
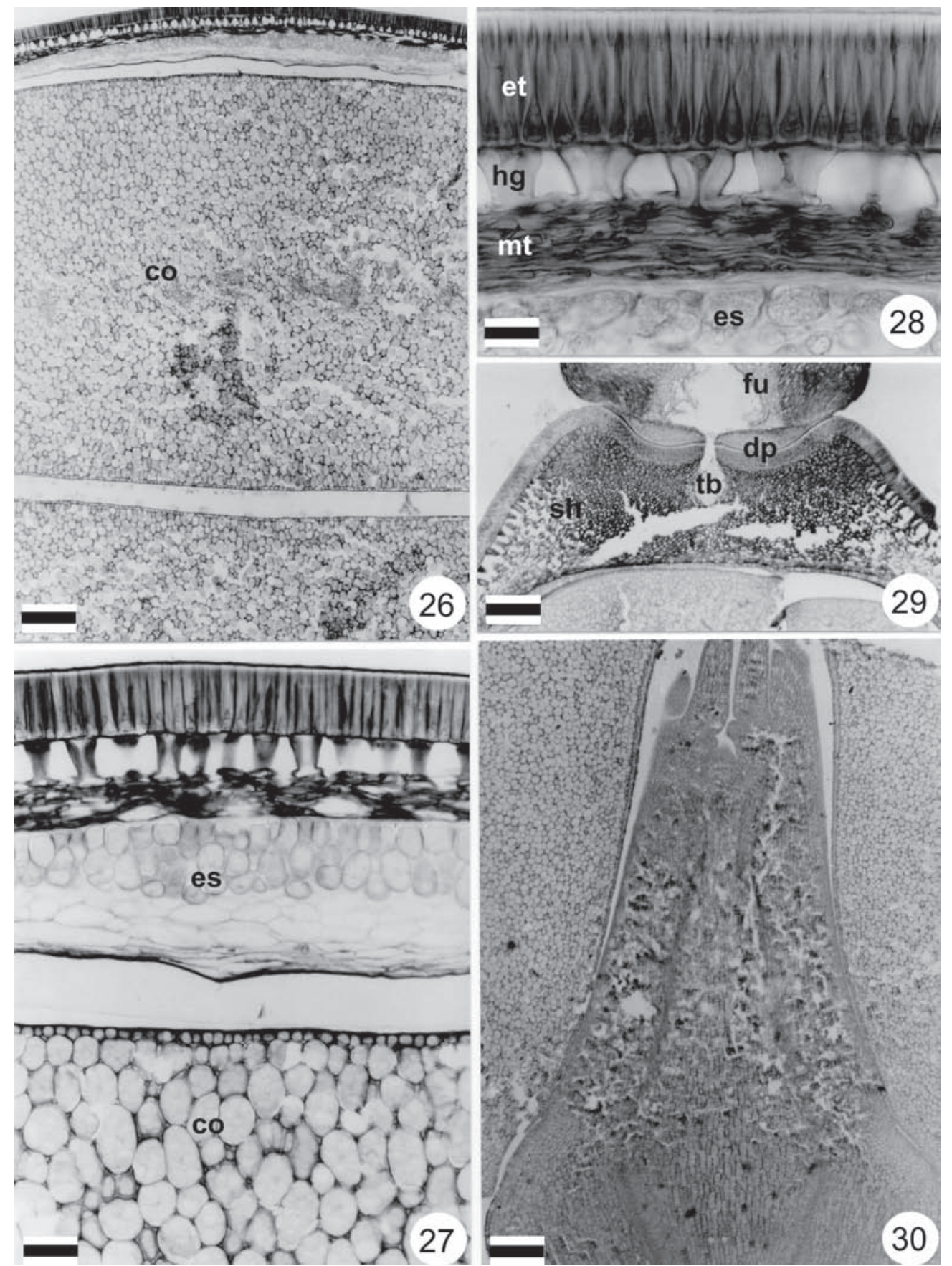

Figs. 26-30 - Pterodon emarginatus mature and soaking seed (transverse sections, except for 30, which is longitudinal). 26. General view of the seed highlighting the testa, endosperm, and cotyledons ratio. 27-28. Details of Fig. 26. 29. Hilum region. 30. Embryo. (co: cotyledon, dp: double palisade layer, ea: embryo axis, es: endosperm, et: exotesta, fu: funicle, hg: hourglass-cells, mt: mesotesta, sh: subhilar parenchyma, tb: tracheid bar). Bars: $200 \mu \mathrm{m}$ (26, 29-30), $100 \mu \mathrm{m}$ (28), $50 \mu \mathrm{m}$ (27). 


\section{DISCUSSION}

Many authors have studied seed structure, particularly the integument, the embryo, or the endosperm. Leguminous seeds are typically testal, produced by bitegmic ovules, in which inner integument reduction frequently occurs (Eames \& MacDaniels, 1953; Corner, 1951, 1976).

In the Fabaceae, endosperm varies from abundant to absent (Corner, 1951, 1976; Gunn, 1981). The studies by De Candolle (1825), following which leguminous embryo structure have been considered of major importance, resulted in the division of the Fabaceae into two great subfamilies based on embryo axis curvature (Curvembriae and Rectembriae). The first subfamily includes the Faboideae and the second, the Caesalpinioideae and Mimosoideae. Although embryo axis curvature is presently not regarded as the best character for primary divisions in the family, it indicates better protection for the radicle and may be one of a set of seed characters (especially hilar characters) used to separate the Faboideae from the other subfamilies (Gunn, 1981).

Eames \& MacDaniels (1953) generalized about the occurrence of complete absorption of the inner integument and nucellus during leguminous seed development. Singh (1964) and Corner (1976) reported that because the tegmen is crushed at maturity, it does not contribute to the seed-coat. Some species of the three Fabaceae subfamilies, in which the tegmen is absent in the mature structure, have been illustrated by Corner (1951, 1976). Boesewinkel \& Bouman (1984) also reported that the inner integument of Fabaceae is either crushed or reabsorbed. Several cases in the literature confirm this observation, e.g., Indigofera enneaphylla (Deshpande \& Untawale, 1971), Indigofera parviflora (Manning \& Van Staden, 1987), Copaifera langsdorffii (Crestana \& Beltrati, 1988), Lonchocarpus muehlberginaus (Souza, 1988), Inga fagifolia (Oliveira \& Beltrati, 1993), and Tipuana tipu (Martins \& Oliveira, 2001).

Because inner integument reduction is usual in legumes, Calliandra hematocephala is a remarkable exception (Dnyansagar, 1958), as is Pterodon emarginatus seed, since occurrence of inner and outer integument fusion in the seed has been demonstrated. In mature seed, the inner integument remains visible at the micropylar pole.
Although the seed is reported as testal due to significant participation of the outer integument in the seed-coat, cells from both integuments are found in this structure. Thus, the inner epidermis of the testa is developmentally tegmic.

Another distinguishing characteristic is frequent presence of phenolic compounds in the integuments. According to Suárez \& Engleman (1980), testa with phenolic content presents greater hardness, low water permeability, and more resistance to pathogen attack. Boesewinkel \& Bouman (1984) agree that phenolic substances, in addition to producing a typical coloration, increase seed-coat hardness. In Pterodon emarginatus, as phenolic accumulation is restricted to subhilar parenchyma, it can be related to resistance and impermeability increase, thus contributing to the hilum hygroscopic-valve functioning.

A typical characteristic of seeds enclosed in woody indehiscent pericarps is the transference to the pericarp of the protective role of the integuments (Boesewinkel \& Bouman, 1984), with consequent seed-coat structural reduction. As already described for samara seeds in different species, such as Tipuana tipu (Martins \& Oliveira, 2001), Pterodon emarginatus seeds show an unlignified, thin seedcoat, without the typical exotesta structure that Boesewinkel \& Bouman (1984) emphasized as a characteristic of legumes. According to these authors, a less differentiated integument occurs in advanced families with indehiscent fruits, such as the drupaceous. Therefore, the integument protective role is transferred to the extremely hard seedchamber pericarp. But this structure characteristic of legumes is not found in P. emarginatus, as the seed integument is formed in the cryptosamara. However, it shows some remarkable aspects of Faboideae seeds that have been described by Corner (1951, 1976) and Gunn (1981), including a stout hilum with the tracheid bar in the subhilar region and palisade layer duplication as reinforcement, which favors funicle attachment. The testa shows the characteristic formation of a palisade exotesta and hourglass-cells in subepidermal layer.

In general, the Fabaceae seeds are water impermeable, scarifying being a requirement for imbibition and seed germination of most species (White, 1908; Corner, 1951; Quinlivan, 1971). The following factors have been considered as the cause of Fabaceae seed impermeability: the testa palisade 
layer functioning as a mechanical barrier (Corner, 1951), as well as three chemical barriers, one due to external periclinal wall suberization (Quinlivan, 1971); another because of cuticle formation (White, 1908; Rees, 1911); and a third owing to phenolic compound formation in the testa cells (Werker $e t$ al., 1973).

Because $P$. emarginatus seeds are impermeable, scarifying is needed for germination (Reis $e t$ al., 1985; Ferreira et al., 2001). In addition, because of the integument structure described, the testa is responsible for seed hardness. It must be emphasized that many phenolic idioblasts in the hilum region can contribute to integument impermeability.

Most Fabaceae endospermic seeds show proportionately less endosperm when compared to the embryo. The endosperm is hard, glassy, opaque when dry, and lacks a starch reserve (Martin, 1946). When soaked, the endosperm becomes gelatinous and hyaline (Gunn, 1981). All these characteristics were observed in P. emarginatus, particularly a lipid reserve in the peripheral cell layers, which show high cytoplasmic density. Few studies have analyzed endosperm structure, thus the process of endosperm reserve storage and consumption during maturation and germination is of special interest.

According to Corner (1976), the endosperm is generally absent in Faboideae, and when present, it shows thick cell walls. In contrast, $P$. emarginatus seed shows thin-walled endosperm cells. In this species, the nucellus remains residual and presents thicker cell walls until immediately before maturity. Faboideae species may develop similarly to that described here; however, their nucellus may be confused with the endosperm, as it is sometimes labeled. In this study, the embryo structure was found to coincide with that described for other leguminous species (Oliveira, 1999). In conclusion, large lipid and protein amounts and reduced starch reserves are characteristic of the fleshy cotyledons of $P$. emarginatus.

Acknowledgements - We are grateful to FAPESP (process 2000/ 12469-3) and FUNDUNESP (process 270/2003-DFP) for financial support.

\section{REFERENCES}

BOESEWINKEL, F. D. \& BOUMAN, F., 1984, The seed: structure. pp. 567-610. In: B. M. Johri (ed.), Embryology of angiosperms. Springer-Verlag, Berlin, 830p.
CRESTANA, C. M. \& BELTRATI, C. M., 1988, Morfologia e anatomia das sementes de Copaifera langsdorffii Desf. (Leguminosae-Caesalpinioideae). Naturalia, 13: 45-54.

CORNER, E. J. H., 1951, The leguminous seed. Phytomorphology, 1: 117-150.

CORNER, E. J. H., 1976, The seeds of dicotyledons. University Press, Cambridge, v. 1, 311p., v. 2, 552p.

DE CANDOLLE, A. P., 1825, Mémoires sur la famille des Légumineuses. A. Belin, Paris apud GUNN, C. R., 1981, Seeds of Leguminosae, pp. 913-925. In: R. M. Polhill \& P. H. Raven (eds.), Advances in legume systematics. Part 1, Royal Botanic Gardens, Kew, 425p.

DESHPANDE, P. K. \& UNTAWALE, A. G., 1971, Development of seed and fruit in Indigofera enneaphylla L. Bot. Gaz., 132(2): 96-102.

DNYANSAGAR, V. R., 1958, Embryological studies in the Leguminosae. VIII. Acacia auriculaeformis A. Cunn., Adenanthera pavonina Linn., Calliandra hematocephala Hassk., and Calliandra grandiflora Benth. Lloydia, 21(1): $1-25$.

EAMES, A. J. \& MacDANIELS, L. H., 1953, An introduction to plant anatomy. Tata McGraw-Hill Publishing, New Delhi, $518 \mathrm{p}$.

FERREIRA, R. A., VIEIRA, M. G. G. C., VON PINHO, E. V. R. \& TONETTI, O. A. O., 2001, Morfologia da semente e de plântulas e avaliação da viabilidade da semente de sucupira-branca (Pterodon pubescens Benth. - Fabaceae) pelo teste de tetrazólio. Rev. Bras. Sem., 23: 108-115.

GUNN, C. R., 1981, Seeds of Leguminosae, pp. 913-925. In: R. M. Polhill \& P. H. Raven (eds.), Advances in legume systematics. Part 1, Royal Botanic Gardens, Kew, 425p.

JENSEN, W. A., 1962, Botanical histochemistry: principles and pratice. W.H. Freeman, San Francisco, 408p.

JOHANSEN, D. A., 1940, Plant Microtechnique. McGraw-Hill Book, New York, 523p.

JUDD, W. S., CAMPBELL, C. S., KELlOGG, E. A. \& STEVENS, P. F., 1999, Plant Systematics: a phylogenetic approach. Sinauer Associates, Sunderland, 464p.

KARNOVSKY, M. J., 1965, A formaldehyde-glutaraldehyde fixative of high osmolality for use in electron microscopy. J. Cell Biol., 27: 137A-138A.

LORENZI, H., 1992, Árvores brasileiras: manual de identificação e cultivo de plantas arbóreas nativas do Brasil. Plantarum, Nova Odessa, 168p.

MANNING, J. C. \& VAN STADEN, J., 1987, The functional differentiation of the testa in seed of Indigofera parviflora (Leguminosae: Papilionoideae). Bot. Gaz., 148(1): 23-34.

MARTIN, A. C., 1946, The comparative internal morphology of seeds. Am. Midl. Natur., 36: 513-660.

MARTINS, M. A. G. \& OLIVEIRA, D. M. T., 2001, Morfoanatomia e ontogênese do fruto e semente de Tipuana tipu (Benth.) O. Kuntze (Fabaceae: Faboideae). Rev. Bras. Bot., 24: 109-121.

MAZIA, D., BREWER, P. A. \& ALFERT, M., 1953, The cytochemistry staining and measurement of protein with mercuric bromophenol blue. Biol. Bull., 104: 57-67. 
O'BRIEN, T. P., FEDER, N. \& McCULLY, M. E., 1964 Polychromatic staining of plant cell walls by toluidine blue O. Protoplasma, 59: 368-373.

OLIVEIRA, D. M. T., 1999, Morfo-anatomia do embrião de leguminosas arbóreas nativas. Rev. Bras. Bot., 22: 413-427.

OLIVEIRA, D. M. T. \& BELTRATI, C. M., 1993, Aspectos anatômicos dos frutos e sementes em desenvolvimento de Inga fagifolia (Fabaceae: Mimosoideae). Rev. Brasil. Biol., 53(4): 625-636.

POLHILL, R. M., 1981a, Papilionoideae, pp.191-204. In: R. M. Polhill \& P. H. Raven (eds.), Advances in legume systematics, Part 1, Royal Botanic Gardens, Kew, 425p.

POLHILL, R. M., 1981b, Tribe 3. Dipteryxeae Polhill, pp. 231232. In: R. M. Polhill \& P. H. Raven (eds.), Advances in legume systematics. Part 1, Royal Botanic Gardens, Kew, $425 \mathrm{p}$.

POLHILL, R. M., RAVEN, P. H. \& STIRTON, C. H., 1981, Evolution and systematics of the Leguminosae, pp. 1-26. In: R. M. Polhill \& P. H. Raven (eds.), Advances in legume systematics. Part 1, Royal Botanic Gardens, Kew, 425p.

QUINLIVAN, B. J., 1971, Seed coat impermeability in legumes. The Journal of the Australian Institute of Agricultural Science, 37: 283-293.

RAVEN, P. H. \& POLHILL, R. M., 1981, Biogeography of the Leguminosae, pp. 27-34. In: R. M. Polhill \& P. H. Raven (eds.), Advances in legume systematics. Part 1, Royal Botanic Gardens, Kew, 425p.
REES, B., 1911, Longevity of seeds and structure and nature of seed coat. Proc. R. Soc. Victoria, New Series, 23: 393-414.

REIS, G. G., BRUNE, A. \& RENA, A. B., 1985, Estudos sobre a dormência de sementes de sucupira (Pterodon pubescens Benth.): tratamentos para superação da dormência. Rev. Árvore, 9: 49-57.

SASS, J. E., 1951, Botanical Microtechnique. 3. ed. State Press, Iowa, 228p.

SINGH, B., 1964, Development and structure of Angiosperm seed - I. Review of the indian work. Bull. Nat. Bot. Gardens, 89: 1-115.

SOUZA, L. A., 1988, Anatomia de estádios de desenvolvimento da semente de Lonchocarpus muehlbergianus Hassl. (Leguminosae-Faboideae). Garcia de Orta, Ser. Botânica, 10(1-2): $1-9$.

SUÁREZ, G. R. \& ENGLEMAN, E. M., 1980, Depósito de taninos en la testa de Amaranthus hypochondriacus L. (alegria). Agrociencia, 42: 35-50.

VON TEICHMAN, I. \& VAN WYK, A. E., 1991, Trends in the evolution of dicotyledonous seeds based on character associations, with special reference to pachychalazy and recalcitrance. Bot. J. Linn. Soc., 105: 211-237.

WERKER, E., DAFNI, A. \& NEGBI, M., 1973, Variability in Prosopis farcata in Israel: anatomical features of the seed. Bot. J. Linn. Soc., 66: 223-232.

WHITE, J., 1908, The occurence of an impermeable cuticle on the exterior of certain seeds. Proc. Royal Soc. Victoria, 21: 203-210. 